\title{
Yield and Sowing Qualities of Winter Bread Wheat Seeds Depending on the Preceding Crops and Sowing Dates in the Forest-Steppe of Ukraine
}

\author{
Andrii Siroshtan ${ }^{1}$, Valerii Kavunets ${ }^{1}$, Oleksandr Derhachov ${ }^{1}$, Serhii Pykalo ${ }^{2,}$, , Liudmyla Ilchenko ${ }^{1}$ \\ ${ }^{1}$ Department of Seed Growing and Agrotechnologies, the V. M. Remeslo Myronivka Institute of Wheat of National Academy of Agrarian \\ Sciences of Ukraine, Tsentralne, Ukraine \\ ${ }^{2}$ Department of Biotechnology, Genetics and Physiology, the V. M. Remeslo Myronivka Institute of Wheat of National Academy of Agrarian \\ Sciences of Ukraine, Tsentralne, Ukraine
}

Email address:

pykalosergiy@gmail.com (S. Pykalo)

${ }^{*}$ Corresponding author

\section{To cite this article:}

Andrii Siroshtan, Valerii Kavunets, Oleksandr Derhachov, Serhii Pykalo, Liudmyla Ilchenko. Yield and Sowing Qualities of Winter Bread Wheat Seeds Depending on the Preceding Crops and Sowing Dates in the Forest-Steppe of Ukraine. American Journal of Agriculture and Forestry. Vol. 9, No. 2, 2021, pp. 76-82. doi: 10.11648/j.ajaf.20210902.15

Received: February 24, 2021; Accepted: March 11, 2021; Published: March 22, 2021

\begin{abstract}
Wheat is one of the most important crops in the world due to its wide geographical adaptation and nutritional value. The use of high-quality seeds of the best varieties being adapted to local growing conditions is an important requirement for increasing wheat yields. The purpose of this research was to establish the influence of preceding crops and sowing dates on yield and seed sowing quality of winter bread wheat varieties. On average, maximum yield capacity in 2016-2018 was obtained in the variety Trudivnytsia myronivska ( $7.41 \mathrm{t} / \mathrm{ha}$ ) when sowing on 15 September after green manure, the minimum yield was in the variety MIP Kniazhna (4.03 t/ha) when sowing on 15 October after soybean as preceding crop. Shifting the sowing dates to later ones led to decrease in yield capacity by 0.97 and 0.62 t/ha after the preceding crops green manure and soybean, respectively. After the preceding crop soybean, the maximum yield (5.77 t/ha) was formed by the variety MIP Valensiia when sowing on 25 September. By ANOVA it was found that the level of wheat yield was the most significantly affected by hydrothermal conditions of the year $(63 \%)$, the interaction "preceding crop $\times$ conditions of the year" $(12 \%)$ and preceding crop $(11 \%)$. It was revealed that an increase in weight of 1000 seeds in the varieties on average was $3.9 \mathrm{~g}$ after the preceding crop green manure in comparison with the preceding crop soybean. There was a slight effect of preceding crops and sowing dates on seed vigor and laboratory germination. These rates were slightly higher for early and optimal sowing dates after green manure as compared with the soybean. Thus, it was confirmed that in the Right-Bank Forest-Steppe green manure is the best preceding crop for seed production, especially for growing pre-basic seeds, while 15 and 25 September are the best sowing dates. For the preceding crop soybean, when sowing on 25 September and 05 October, the yield of wheat varieties was the highest in comparison with sowing on 15 October. Locations of winter wheat seed crops after the best preceding crops in crop rotation and optimal sowing dates will promote the most efficient using of climatic and anthropogenic factors, increase grain yield per area unit, and improve seed sowing quality.
\end{abstract}

Keywords: Yield, Preceding Crop, Sowing Quality, Winter Bread Wheat, Sowing Dates

\section{Introduction}

Winter wheat in Ukraine is grown with using modern intensive technology, which is based on optimization conditions for its growth and development. The technology needs placing the crop after the best preceding crops, using intensive varieties and applying fertilizers to the planned yield, an integrated system of plant protection against weeds, diseases and pests. To increase wheat yield it is important to sow high-quality seeds of the best zoned varieties that are adapted to local growing conditions [1].

However, Zhemela H. P. and Shakalii S. M. indicate that a 
significant part of winter wheat crops is located after preceding crops which do not provide optimal conditions for growth and development. This leads to a decrease in productive moisture in the soil, accumulation of pests, pathogens, toxins, irrational using of nutrients and, therefore, to reduced yields and deterioration of grain and seeds [2].

Therefore, in order to provide farms with high-quality seeds, it is necessary to use seed crop rotations and optimal sowing dates for new varieties of winter bread wheat. To obtain high and stable winter wheat yields, the most important issue is the development of adaptive cultivation technologies that would take into account the adaptation of plants to the specific conditions of the growing region [3].

In the process of intensification of agriculture, the attitude to the assessment of preceding crops and sowing dates changes, because there is a need to sow after such preceding crops which are considered insufficiently favorable at the current level of agricultural development [4-6].

The sowing dates in winter wheat growing are no less important than tillage and fertilization. The intensity of plant growth in autumn, as well as accumulation of storing substances in the leaves and nodes of tillering, the acquisition of plant resistance to adverse wintering conditions are closely related to this agronomic measure. The degree of plant damage by pests and the impact of diseases depend on the sowing dates $[7,8]$.

Favorable weather conditions during the growing season are necessary to obtain high yields, but they depend on environmental factors that cannot be adjusted. However, by changing the sowing dates within acceptable limits, it is possible to affect the supply of plants with heat and solar radiation, that is it indirectly optimize the "uncontrolled" factors of crop growing [9, 10]. Sowing in optimal terms should ensure winter wheat plants to passage in autumn at those stages of organogenesis which subsequently determines the level of viability of agrobiocenosis and its productivity [11].

According to Kononiuk L. M. and Kymak Ya. V., as a result of early sowing winter wheat plants at autumn vegetation dormancy onset date formed 1,500-1,800 shoots at the normal $1,000-1,200 \mathrm{pcs} / \mathrm{m}^{2}$. Such crops were affected by diseases and damaged by pests, which reduced yield and deteriorated grain quality [12].

Druz'iak V. H. points out that when sowing winter crops at different dates, different abiotic conditions are modeled, i.e. air temperature, the sum of positive temperatures, day length and precipitation. Therefore, for the production of high quality seeds of new and promising varieties of winter wheat and barley it should be evaluated variety response to different abiotic conditions [13].

Studies have shown that change in sowing dates from optimal to both early and late led to a sharp decrease in yield $[14,15]$. Numerous studies have shown that the highest wheat yield was formed at the optimal sowing dates and seeding rates, which were chosen depending on soil and climatic conditions, preceding crop, biological characteristics of varieties, autumn temperature conditions and soil moisture
[16-20].

Tsvei Ya. P., Lenshyn O. H. and Konopelskyi M. I. reported about different influence of preceding crops on the formation of soil fertility indicators, crop yield and quality indicators [21]. Stability of yield and grain quality depends on a positive solution to the problem of preceding crops. The stability of crop rotations over time, the timing of fieldwork and increase the efficiency of the system of agronomic measures for growing crops in crop rotation is the main reserve for increasing grain production [22].

Moisture for winter wheat is needed from sowing to harvest, although at different stages of organogenesis plants need it in different amounts. The need of this crop for water depends on soil and air humidity, temperature, plant condition, as well as the intensity of solar radiation. Therefore, the creation of a normal water regime of the soil, especially in areas of unstable rainfed environment, is in priority [23, 24].

The best preceding crops of winter wheat include pure, occupied and green manure fallows, and among previous crops they are peas, alfalfa, corn for green fodder and for silage, early maturing soybean varieties [25]. In the Forest-Steppe the winter crop yield after vetch harvested for green fodder or hay is not inferior to the yield after pure fallow [26].

It is known that previous crops leave different amounts of moisture and nutrients available to plants in the soil, determine the structural condition of the soil and the level of crop contamination [27-30]. The agronomic value of preceding crops for winter wheat is their ability to provide the fields with the necessary moisture to obtain even seedlings, for good development of root system and aboveground vegetative mass in autumn, as well as further normal growth and development of plants in spring. It should also be noted that the preceding crops affect not only the water regime of winter wheat, but also its nutrition [31], disease development and pest damage $[32,33]$, as well as weediness [34].

Hospodarenko H. M. and Lysianskyi O. L. proved that applying fertilizers can replenish nutrient reserves, and weeds can be neutralized by modern effective means [35]. Review of these studies shows a significant effect of preceding crops on the soil moisture level at the time of sowing winter wheat. It is often noted that the reserves of productive moisture in one meter layer of soil at the time of the optimal sowing dates largely determine the level of its yield. There is an almost direct relationship between these rates with correlation level of 0.57-0.94 [36].

Breeder V. V. Shelepov stated [37] that new varieties of winter wheat due to their biological characteristics (resistance to lodging and disease, high winter hardiness, etc.) make full using of the potential after best preceding crops.

Original seeds in modern conditions of agriculture intensification are of very importance. It allows in the appropriate growing conditions to realize the biological potential of the variety. Both the level of crop yield and grain quality depends on using quality seeds. When using high-quality seeds of the best zoned varieties of winter wheat, the grain yield can increase by $15-20 \%$ compared to the 
cultivation of old varieties [38].

The great importance of these factors is shown for the formation of seed quality of winter wheat. The production of winter wheat seeds in different environmental conditions leads to the formation of different quality. First of all, the size of the seed changes, which determines the peculiarities of growth and development of plants in the early stages of its ontogenesis [39]. Intensification of wheat cultivation technology also affects the yield of conditioned seeds and their seed and yield qualities [40]. The yield and quality of winter wheat seeds are significantly affected by various factors, including preceding crops, which largely determine the conditions for plant growth and development [41]. Therefore, the location of winter wheat crops in crop rotation after the best preceding crops is important in the cultivation of this crop for both commercial purposes and seeds.

The aim of the research is to establish the influence of preceding crops and sowing dates on the yield and sowing qualities of seeds of winter bread wheat varieties.

\section{Materials and Methods}

The research was carried out at the Department of Seed Production and Agrotechnologies of the V. M. Remeslo Myronivka Institute of Wheat (MIW) during 2016-2018 using new winter wheat varieties listed in the State Register of Plant Varieties Suitable for Dissemination in Ukraine.

The soils of the experimental field are deep chornozem, low-humus and slightly silted. These soils contain 3.6-4.5\% humus, 5.5-6.4 mg of hydrolyzed nitrogen, 19.0-27.1 mg of mobile phosphorus, $11.2-18.0 \mathrm{mg}$ of exchangeable potassium per $100 \mathrm{~g}$ of soil, pH 5.3-6.4, the sum of absorbed bases 23.1$28.6 \mathrm{mEq}$. per $100 \mathrm{~g}$ of soil, the degree of saturation with bases is $86.2-94.4 \%$.

The scheme of the experiment included: factor A - varieties:
MIP Vyshyvanka, Trudivnytsia myronivska, MIP Valensiia, MIP Kniazhna, Myronivska slava; factor B - preceding crops: green manure, soybean; factor C - sowing dates (15 September, 25 September, 05 October, and 15 October).

Agrotechnical conditions during the research are generally accepted: chopping plant residues, leveling of the soil surface, application of basic fertilizer $\mathrm{N}_{60} \mathrm{P}_{60} \mathrm{~K}_{60} \mathrm{~kg} / \mathrm{ha}$ a.s. (ANP fertilizer $\mathrm{N}_{16} \mathrm{P}_{16} \mathrm{~K}_{16}$ ). Seed treatment was performed with the Yunta Quattro, FS, $1.5 \mathrm{l} / \mathrm{t}$. The sowing rate was 5 million viable seeds per 1 ha (with seed drill SN-10ts). The estimated area of the plot was $10 \mathrm{~m}^{2}$, in 4 replications. At the IV stage of organogenesis, the plants were fertilized with nitrogen (ammonium nitrate) at the rate of $\mathrm{N}_{34}$ a.s./ha, and the crops were treated with tank mixture of herbicide Pointer 75, WG, $25 \mathrm{~g} / \mathrm{ha}$, fungicide Amistar Extra $280 \mathrm{SC}, 0.75$ 1/ha and adhesive agent Trend 90, $200 \mathrm{ml} / \mathrm{ha}$. The crop was harvested by direct combining "Sampo-130" and converted to standard (14\%) grain moisture.

Mathematical processing of experimental data was performed by the method of analysis of variance [42]. Sowing qualities were determined according to DSTU 4138-2002 [43].

\section{Results}

The hydrothermal conditions of 2015-16-2017-18 had significant differences (Table 1). In general, increased air temperatures were observed. Thus, the average air temperature in the period from August to July 2015-16 and 2017-18 vegetation years was 10.3 and $9.9^{\circ} \mathrm{C}$, which was 2.1 and $1.7^{\circ} \mathrm{C}$ higher than the average long-term, respectively. The most variation in average monthly temperatures over the years was observed mainly from November to March. The sharp and significant increase in air temperature occurred in late March - early April 2018.

Table 1. Hydrothermal conditions in cropping seasons 2015-16-2017-18.

\begin{tabular}{|c|c|c|c|c|c|c|c|c|c|c|c|c|c|}
\hline \multirow{2}{*}{ Year } & \multicolumn{12}{|c|}{ Month } & \multirow{2}{*}{$\begin{array}{l}\text { In a } \\
\text { year }\end{array}$} \\
\hline & VIII & IX & $\mathbf{X}$ & $\mathbf{X I}$ & XII & I & II & III & IV & $\mathbf{V}$ & VI & VII & \\
\hline \multicolumn{14}{|l|}{ Air temperature, ${ }^{\circ} \mathrm{C}$} \\
\hline Average long-term & 19.5 & 14.4 & 8.2 & 2.2 & -2.3 & -4.6 & -3.7 & 1.2 & 9.1 & 15.3 & 18.5 & 20.2 & 8.2 \\
\hline $2015-16$ & 21.5 & 18.2 & 7.1 & 4.7 & 1.8 & -5.8 & 2.4 & 4.2 & 12.4 & 15.2 & 20.1 & 22.2 & 10.3 \\
\hline $2016-17$ & 21.1 & 15.7 & 6.7 & 1.4 & -1.8 & -5.3 & -2.6 & 6.0 & 10.4 & 15.4 & 20.6 & 20.9 & 9.0 \\
\hline $2017-18$ & 22.4 & 17.0 & 8.6 & 3.5 & 2.2 & -2.9 & -3.6 & -1.8 & 13.3 & 18.4 & 20.2 & 21.1 & 9.9 \\
\hline \multicolumn{14}{|l|}{ Total rainfall, mm } \\
\hline $2015-16$ & 10 & 44 & 27 & 46 & 19 & 72 & 51 & 36 & 55 & 92 & 69 & 19 & 539 \\
\hline 2016-17 & 37 & 2 & 75 & 44 & 31 & 31 & 33 & 12 & 43 & 23 & 20 & 102 & 453 \\
\hline $2017-18$ & 20 & 13 & 74 & 52 & 115 & 63 & 37 & 93 & 21 & 33 & 97 & 79 & 697 \\
\hline
\end{tabular}

In the period from August 2015 to July 2016, $539 \mathrm{~mm}$ of precipitation fell, which was $93 \%$ of the average long-term amount. The 2016-17 growing season was sharply arid 453 $\mathrm{mm}(78 \%)$. In 2017-18, the amount of precipitation was 697 $\mathrm{mm}(120 \%)$. It should be noted a significant variation in precipitation by month, their uneven precipitation over time, as well as the lack in critical periods for plants - September 2016, March, May, June and September 2017, April and May 2018. The maximum average yield in 2016-2018 was obtained in the variety Trudivnytsia myronivska $(7.41 \mathrm{t} / \mathrm{ha})$ when sowing on 15 September after green manure, the minimum yield was in the variety MIP Kniazhna (4.03 t/ha) when sowing on 15 October after soybean (Figure 1).

The shift of wheat sowing dates to later ones led to a decrease in the yield of varieties by 0.97 and $0.62 \mathrm{t} / \mathrm{ha}$ according to the preceding crops green manure and soybean, respectively. According to the soybean as preceding crops, the maximum yield $(5.77 \mathrm{t} / \mathrm{ha})$ was formed by the variety MIP 
Valensiia when sowing on 25 September.

ANOVA found that the level of wheat yield was the most significantly affected by hydrothermal conditions of the year
$(63 \%)$, the interaction of "preceding crop $\times$ conditions of the year" $(12 \%)$ and preceding crop (11\%). Other factors had a less effect on the yield of winter bread wheat (Figure 2).

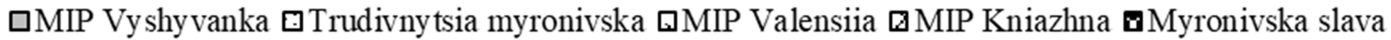

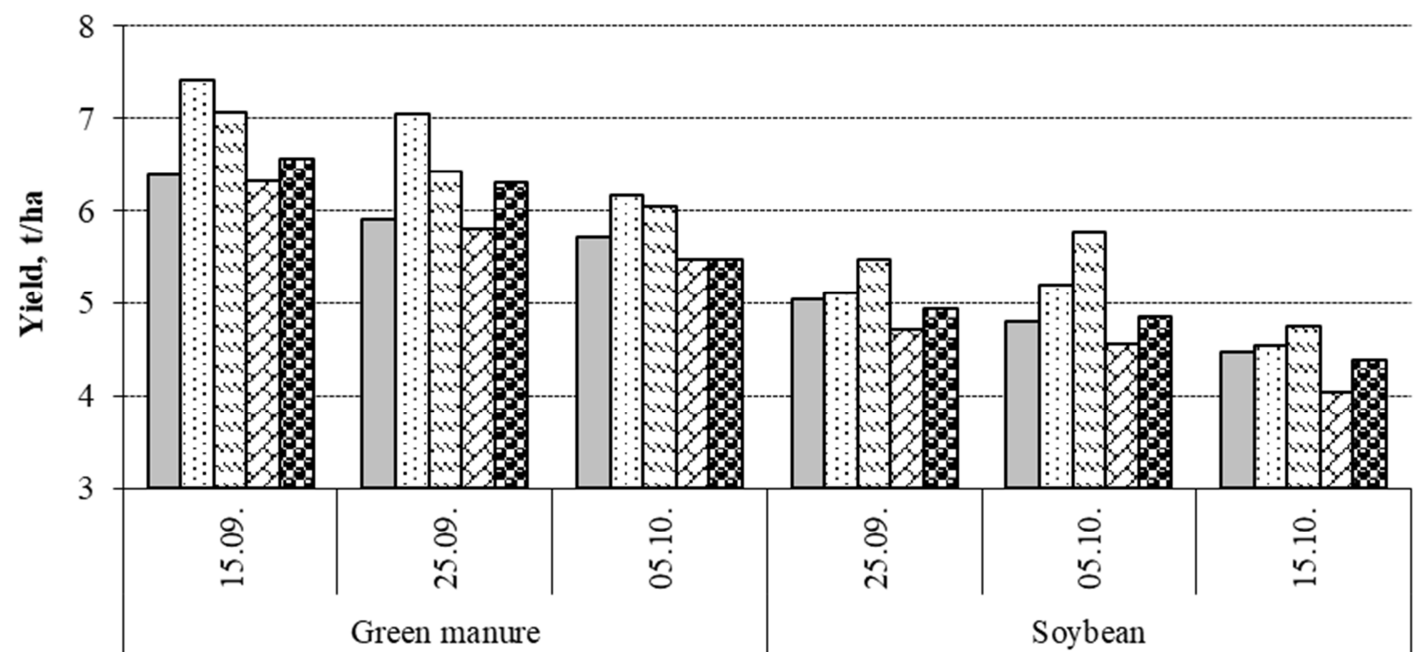

Figure 1. Yield of winter bread wheat varieties depending on preceding crops and sowing dates, t/ha (MIW, 2016-2018).

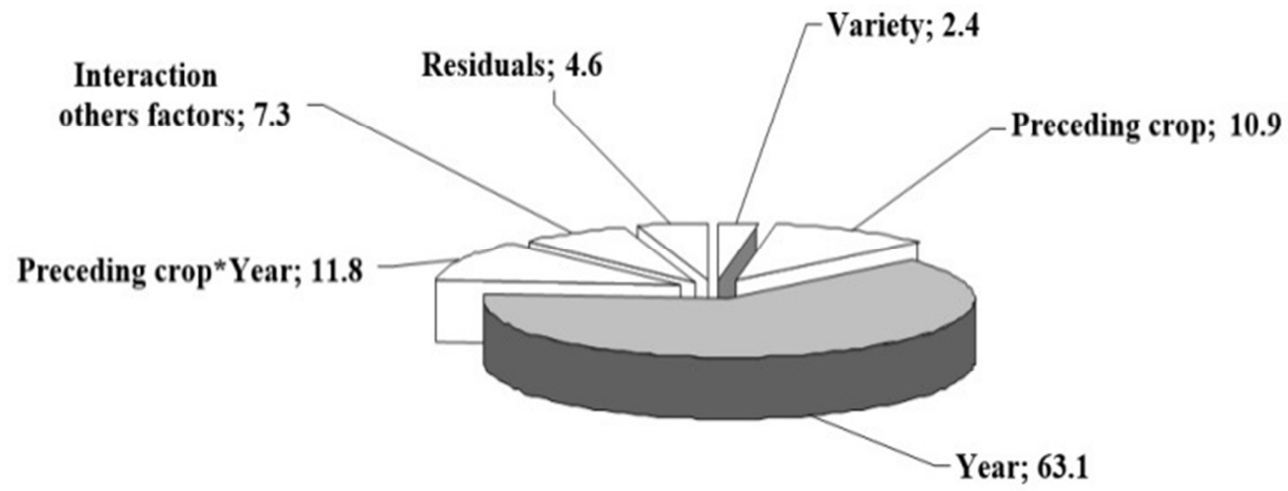

Figure 2. Influence of factors on grain yield of winter wheat, \% (MIW, 2016-2018).

High-quality seeds of winter wheat are known to be formed under optimal growing conditions. Any deviation from the optimal mode of cultivation of mother plants can lead to deterioration of both individual characters of sowing qualities and their complex [44].

Thus, the average weight of 1000 seeds of varieties under study varied significantly by variants (Table 2 ).

Table 2. Weight of 1000 seeds of winter bread wheat varieties depending on the preceding crops and sowing dates, $g$ (MIW, 2016-2018).

\begin{tabular}{|c|c|c|c|c|c|c|c|}
\hline Preceding crop & Sowing date & MIP Vyshyvanka & Trudivnytsia myronivska & MIP Valensiia & MIP Kniazhna & Myronivska slava & average \\
\hline \multirow{4}{*}{ Green manure } & 15.09 & 45.4 & 46.8 & 47.4 & 46.7 & 46.4 & 46.5 \\
\hline & 25.09 & 44.8 & 45.5 & 44.8 & 45.6 & 44.8 & 45.1 \\
\hline & 05.10 & 43.3 & 42.4 & 43.4 & 44.3 & 43.5 & 43.4 \\
\hline & average & 44.5 & 44.9 & 45.2 & 45.5 & 44.9 & 45.0 \\
\hline \multirow{3}{*}{ Soybean } & 25.09 & 43.1 & 42.6 & 43.3 & 42.4 & 42.3 & 42.7 \\
\hline & 05.10 & 42.2 & 41.6 & 41.9 & 42.1 & 41.0 & 41.8 \\
\hline & 15.10 & 38.5 & 38.8 & 40.3 & 39.5 & 37.4 & 38.9 \\
\hline $\mathrm{LSD}_{0.05}$ & & 1.2 & & & & & \\
\hline
\end{tabular}

The maximum weight of 1000 seeds was formed by the variety MIP Valensiia (47.4 g) when sowing on 15 September after the preceding crop green manure, and the minimum was in the variety Myronivska slava (37.4 g) when sowing on 15 October after soybean. The average weight of 1000 seeds of varieties after green manure as compared to soybean prevailed by $3.9 \mathrm{~g}$.

The influence of preceding crops and sowing dates on seed vigor was not detected, it was only noted that this indicator was slightly higher in some varieties after green manure in 
comparison with the preceding crop soybean (Table 3).

Table 3. Seed vigor of winter bread wheat varieties depending on preceding crops and sowing dates, \% (MIW, 2016-2018)

\begin{tabular}{llllllll}
\hline Preceding crop & Sowing date & MIP Vyshyvanka & Trudivnytsia myronivska & MIP Valensiia & MIP Kniazhna & Myronivska slava & average \\
\hline \multirow{5}{*}{ Green manure } & 15.09 & 94 & 93 & 94 & 95 & 95 & 94 \\
& 25.09 & 93 & 94 & 94 & 95 & 94 & 94 \\
& 05.10 & 93 & 92 & 92 & 94 & 94 & 93 \\
& average & 93 & 93 & 93 & 95 & 94 & 94 \\
Soybean & 25.09 & 93 & 93 & 93 & 94 & 93 & 93 \\
& 05.10 & 92 & 92 & 92 & 92 & 93 & 92 \\
LSD $_{0.05}$ & 15.10 & 91 & 92 & 92 & 93 & 93 & 92 \\
\hline
\end{tabular}

Laboratory germination of seeds is a quantitative indicator of their quality which is a measure of viability and is determined by the percentage of normally germinated seeds for a certain time in optimal conditions. In seeds with reduced germination, the yield properties deteriorate sharply and often, even by increasing the sowing rate, it is impossible to achieve a high yield [45].

As a result of the research, no special influence of preceding crops and sowing dates on laboratory germination of seeds was detected, only an insignificant decrease was noted when sowing wheat varieties on 15 October after soybean (Figure 3).

\section{Conclusions}

Location of winter wheat areas for seed production after the best preceding crops in crop rotation and optimal sowing dates contribute to the most efficient usage of natural, climatic and anthropogenic factors, increasing grain yield per unit area and improving seed sowing qualities.

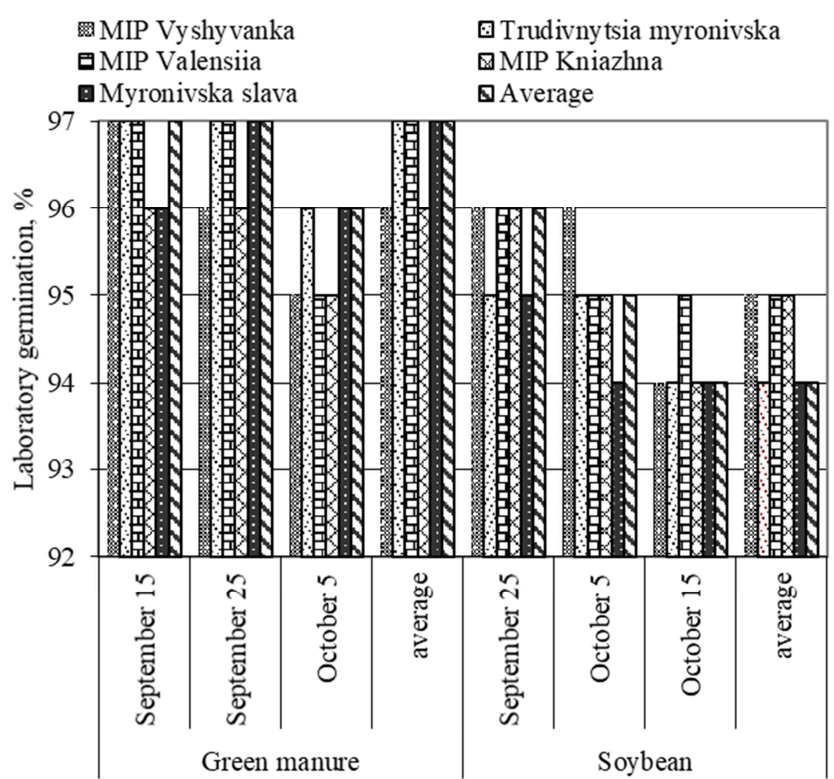

Figure 3. Laboratory germination of seeds of winter bread wheat varieties depending on preceding crops and sowing dates, \% (MIW, 2016-2018).

It is proved that in the Right-Bank Forest-Steppe the best preceding crop for seed crops, especially for growing pre-basic seeds, was green manure, and the sowing dates are
15 and 25 September. Thus, in 2016-2018, when sowing on 15 September after green manure, the wheat variety Trudivnytsia myronivska formed on average maximum yield of $7.41 \mathrm{t} / \mathrm{ha}$. After soybean the maximum yield of $5.77 \mathrm{t} / \mathrm{ha}$ was formed by the variety MIP Valensiia when sowing on 25 September.

Shifting the sowing dates to later ones decreased in yield by 0.97 and $0.62 \mathrm{t} / \mathrm{ha}$ after green manure and soybean, respectively.

There was a slight effect of preceding crops and sowing dates on seed vigor and laboratory germination. These characters were slightly higher for early and optimal sowing dates after the preceding crop green manure in comparing to the soybean.

\section{Recommendations}

The research will promote more effective use of wheat varieties studied both in crop production and in seed production. The obtained results contribute to the improvement of techniques of growing pre-basic, basic, and certified seeds of new wheat varieties in seed farms.

\section{References}

[1] Ovcharuk, O. V., Ovcharuk, V. I., Ovcharuk, O. V., Khomina, V. Ya., Mostipan, M. I., Kulyk, H. A. (2019). Methods of analysis in agronomy and agroecology: a textbook. Kamianets-Podilskyi; Kharkiv, Machulyn, 364.

[2] Zhemela, H. P., Shakalii, S. M. (2012). The predecessors influence on grain yield and quality of soft winter wheat. Bulletin of Poltava State Agrarian Academy, 3, 20-22.

[3] Petrychenko, V. F., Lykhochvor, V. V. (2017). Up-to-date technologies in plant growing in historical foreshortening and view of euro integration calls. Bulletin of Agricultural Science, $9,5-10$.

[4] Derhachov, O. L. (2010. Sowing terms of winter bread wheat varieties (Triticum aestivum L.) in the conditions of climate change. Plant Varieties Studying and Protection, 1 (11), 3336.

[5] Petrychenko, V. F., Korniichuk, O. V. (2018). Factors of stabilization of winter wheat grain production in the Right-bank Forest-steppe. Bulletin of Agricultural Science, 2, 17-23. 
[6] Davydenko, H. A. (2012). Influence of preceding crops and fertilizers on agrochemical parameters of soil and productivity of winter wheat. Bulletin of Sumy National Agrarian University. Agronomy and Biology Series, 9 (24), 37-39.

[7] Liashenko, V. V., Marenych, M. M. (2010). Influence of sowing terms on the yield of winter wheat. Bulletin of Poltava State Agrarian Academy, 2, 46-50.

[8] Vlasiuk, O. S., Kyryliuk, D. P., Voitov, O. D., Naraievska, O. O. (2013). Yield and phytosanitary condition of winter wheat depending on sowing dates and sowing rates. Collection of scientific works of Podilsk State Agrarian and Technical University, 21, 48-52.

[9] Sokolovska, I. M., Konoplia, M. I., Makhmud, M. S. A. B. (2010). Terms of sowing and sowing rates of winter barley in the Northern Steppe of Ukraine. Taurida Scientific Herald, (73), 35-39.

[10] Feoktistoff, P. O., Blyshchyk, D. V. (2014). Effects of climate change on winter wheat sowing terms in the Southern Ukraine. Man and Environment. Issues of Neoecology, 1-2. 56-61.

[11] Chetveryk, O. M. (2011). Influence of sowing dates and weather conditions of the autumn vegetation period on overwintering and yield of soft winter wheat. Bulletin of the Center for Science Provision of Agribusiness in the Kharkiv region, 10, 265-273.

[12] Kononiuk, L. M., Kymak, Ya. V. (2009). Productivity of winter wheat at different sowing dates. Collection of Scientific Works of NSC "Institute of Agriculture UAAS", 114-122.

[13] Druziak, V. H. (2002). Influence of sowing dates of new varieties of winter soft wheat on grain yield. Agrarian Bulletin of the Black Sea Littoral, 18, 15-16.

[14] Vozhehova, R. A., Zaiets, S. O., Kovalenko, O. A. (2013). Yields of different varieties of winter wheat depending on the timing of sowing in the southern steppe. Bulletin of Agricultural Science, 11, 26-29.

[15] Netis, I. T. (2011). Winter wheat in the south of Ukraine. Kherson, Oldi-plius, 460.

[16] Zheliazkov, O. I. (2011). Formation of indicators of quality of winter wheat grain from predecessors, terms of sowing and norms of sowing of seeds in Prisyvashsha. Bulletin of Institute of Grain Farming, 40, 175-179.

[17] Smetanko, O. V. (2012). Influence of winter wheat cultivation technologies after pea predecessor on yield, grain quality and economic efficiency. Agrarian Bulletin of the Black Sea Littoral, 61, 67-72.

[18] Buzynnyi, M. V. (2015). Productivity of winter wheat depending on predecessors. Collection of scientific works of NSC "Institute of Agriculture NAAS", 2, 106-116.

[19] Cherenkov, A. V., Palchuk, N. S. (2015). Influence of weather conditions and fore-crops on winter resistance of different varieties of winter wheat in northern Steppe of Ukraine. Proceedings of the National Academy of Sciences of Belarus, 1, 69-74.

[20] Babulicova, M. (2014). The influence of fertilization and crop rotation on the winter wheat production. Plant Soil Environment, 60 (7), 297-302.
[21] Tsvei Ya. P., Lenshyn, O. H., Konopelskyi, M. I. (2012). Yield and grain quality of winter wheat depending on the predecessor in the Right-Bank Forest-Steppe. Collection of scientific works of NSC "Institute of Agriculture NAAS", 12. $15-20$.

[22] Gathala, M. K., Timsina, J., Islam, M. S., Rahman, M. M., Hossain, M. I., Harun-Ar-Rashid, M., McDonald, A. (2015). Conservation agriculture based tillage and crop establishment options can maintain farmers' yields and increase profits in South Asia's rice-maize systems: Evidence from Bangladesh. Field Crops Research, 172, 85-98.

[23] Kostyria, I. V. (2012). Yield of winter wheat grain and its level of quality depending on predecessors and fertilizer system in the conditions of near Syvash area. Irrigated Agriculture, 58, $51-53$.

[24] Kiriiak, Yu. P., Trykoz, L. V. Kovalenko, A. M. (2015). Water regime of soil in winter wheat crops under conditions of different placement in crop rotation and tillage. Irrigated Agriculture, 64, 61-64.

[25] Kramarev, S. Artemenko, S. (2012). Views on the record. Grain, 12, 44-56.

[26] Klysha, A., Kulinich, O. Spring vetch (peas) (2013). The Ukrainian Farmer, 6 (46), 66.

[27] Hospodarenko, H. M., Lysianskyi, O. L. (2015). Allelopathic impact of green manure crops on winter wheat. Bulletin of Zhytomyr Agroecological University, 2 (50), 190-198.

[28] Isbell, F., Craven, D., Connolly, J., Loreau, M., Schmid, B., Beierkuhnlein, C., Eisenhauer, N. (2015). Biodiversity increases the resistance of ecosystem productivity to climate extremes. Nature, 526 (7574), 574-577.

[29] Palmer, J., Thorburn, P. J., Biggs, J. S., Dominati, E. J., Probert, M. E., Meier, E. A., Parton, W. J. (2017). Nitrogen cycling from increased soil organic carbon contributes both positively and negatively to ecosystem services in wheat agro-ecosystems. Frontiers in Plant Science, 8, 731.

[30] Martyniuk, S., Pikuia, D., Koziei, M. (2019). Soil properties and productivity in two long-tern crop rotations differing with respect to organic matter management on an Albic Luvisol. Scientific Reports, 9, 187.

[31] Koretskyi, O. Ye. (2013). Biological activity of soil in winter wheat crops depending on predecessors in the Forest-Steppe of the Left Bank. Bulletin of Poltava State Agrarian Academy, 2, 146-150.

[32] Kuleshov, A. V., Bilyk, M. O., Dovhan, S. V. (2011). Phytosanitary monitoring and forecast. Kharkiv, Espada, 608.

[33] Tatarynova, V. I., Vlasenko, V. A., Rozhkova, T. O. (2013). Monitoring of the phytopathogenic complex of grain crops of the north-eastern Forest-steppe of Ukraine. Bulletin of Sumy National Agrarian University, Series "Entomology and Biology", 3 (25), 29-33.

[34] Zabarna T. A. (2018). Influence of predecessors on weediness of winter wheat. Agriculture and Forestry, 11, 52-60.

[35] Hospodarenko, H. M., Lysianskyi, O. L. (2016). Recycling of biogenic elements in the soil under different green manures and their fertilization. Collection of scientific works of Uman National University of Horticulture, 88, 7-16. 
[36] Kovalenko, A. M., Tymoshenko, H. Z., Novokhyzhnyi, M. V. (2016). Dynamics of soil water regime in short-rotation crop rotations under different tillage systems. Innovative developments of youth - modern agriculture: materials intern. scientific-practical conf. young scientists. Kherson, Hryn D, $85-87$.

[37] Shelepov, V. V., Gavrilyuk, N. N., Vergunov, V. A. (2013). Wheat: biology, breeding, morphology, seed production. Kiev, Lohos, 498.

[38] Makrushyn, M. M. (1994). Seed science of field crops. Kyiv, Urozhai, 208.

[39] Efremova, V. V., Samelik, E. G. (2015). Tasks and current state of seed production of field crops. Scientific journal of the Kuban State Agrarian University, 106 (02), 84-93.

[40] Mergoum, M., Yomer-Macpherson, H. (2004). Triticale improvement and production. Rome. Food and agriculture organization of the United Nations, 137.

[41] Kavunets, V. P., Kochmarskyi, V. S. (2011). Seed production of winter wheat. Myronivka, 319.

[42] Dospekhov, B. A. (1985). Methods of field experience: 5th ed., add. and rev. Moscow, Agropromizdat, 351.

[43] Seeds of agricultural crops. (2003). Method of determining quality: DSTU 4138-2002. Kyiv, Derzhspozhyvstandart of Ukrainy, 173.

[44] Manzhos, D. M. (1971). Wheat seed science. Kyiv, Urozhai, 171.

[45] Kindruk, M. O., Sokolov, V. M., Vyshnevskyi, V. V. (2012). Seed production with the basics of seed science. Kyiv, Ahrarna nauka, 264. 